\title{
EFFECTS OF SOME ANTIVIRAL AGENTS IN EMERGENCY CASES OF RABIES SIMULATING IN MICE
}

Samy Kasem ${ }^{a}$, Mohamed Khodier ${ }^{b}$, Gabr El-Bagoury, Suzan AbdelFatah ${ }^{a}$

aDepartment of Virology, Faculty of Veterinary Medicine, Kafr El Sheikh University, Kafr El Sheikh, 33516, Egypt

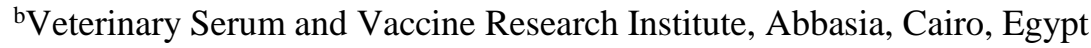

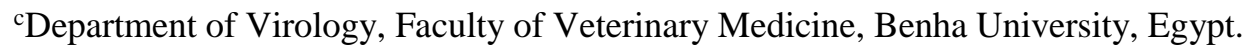

\begin{abstract}
The present study aims mainly to determine the best way to stop rabies infection in naturally exposed victims through the application of antiviral treatment in a comparison with the efficacy of emergency immunization using rabies antiserum and vaccine. All tested concentrations of ribavirin and Acyclovir did not inhibit the cell growth rate and did not affect the cell morphology indicating the drug safety. In vitro studies revealed that 1-200 $\mu \mathrm{g}$ of ribavirin or acyclovir were able to inhibit the CPE of 100 TCID 50 of rabies virus in infected BHK cell culture confirming their antiviral effect. Administration of ribavirin and acyclovir as emergency treatment of rabies infection simulating in mice, revealed that the best time for ribavirin treatment was restricted between 0 time (time of infection) and 2 days post infection showing $100 \%$ protection followed by the treatment on the $3^{\text {rd }}$ day post infection $\left(90 \%\right.$ protection) then the $4^{\text {th }}$ day $(70 \%$ protection). Delayed treatment leads to less protection $(40 \%$ decreased gradually to $10 \%$ by the $5^{\text {th }}$ to $7^{\text {th }}$ day post infection. More delayed treatment resulted in $0 \%$ protection. Administration of acyclovir on 0 times; 1; 2 and 3 days post experimental infection of mice with rabies virus was able to overcome virus infection recording $100 \%$ protection followed by $80 \%$ protection with treatment
\end{abstract}


application on the $4^{\text {th }}$ day. Mice receiving acyclovir after that were unable to withstand the clinical signs of rabies starting from 60 to $0 \%$. Administration of rabies hyper immune serum to experimentally infected mice revealed 100\%; 90\%; $80 \%$ and $70 \%$ protection when such administration was carried out on 0, 1, 2, 3 and 4 days post infection respectively. Delayed administration of rabies hyper immune serum resulted in decrease of the protection \% from $50 \%$ by the day 5 to $0 \%$ by the day 7 post infection. These results investigate that ribavirin, acyclovir and rabies antiserum could be administrated to overcome rabies infection on the main time post exposure.

\section{INTRODUCTION}

Rabies is one of the most feared zoonotic diseases in the world. All worm blooded animals are susceptible to infection by the virus (Woldehiwet, 2005). The disease is known as a highly fatal virus infection of the central nervous system, which occurs in all farm animals and it is transmitted by the bites of affected animals (Radostits et al., 2007). It was reported that rabies is fatal viral encephalitis caused by rabies virus that is mainly transmitted through the saliva of domestic or wild rabid animals (Nishizono, 2009 and Kakuy et al, 2011). The causative agent is a virus in the family Rhabdoviridae, genus Lyssavirus. Regardless of the viral variant found throughout the world, all lyssaviruses cause rabies (Rupprecht et al, 2010).

For control of rabies in dog populations, vaccinating a minimum of $50-70 \%$ of dogs is theoretically necessary. Eliminating wildlife populations is nearly impossible and is expensive. Therefore the control measures centered on vaccination of dogs and cats are most appealing and effective (Green and Rupprecht, 2006). The disease is preventable by timely administration of post exposure prophylaxis (PEP) consisting 
of four or five doses of rabies vaccine combined, in the most sever cases of exposures, with anti-rabies immunoglobulin (RIG). PEP consists of a multimodal approach to decrease an individual's likelihood of developing clinical rabies after a possible exposure to the virus. Every year, approximately 55000 individuals worldwide die due to rabies infection (Bourhy et al, 2009).

Nowadays and according to the increasing population in Egypt; many new cities are developed extending to the desert area. Such extension leads to the increase chance to wild carnivores to attack farm animals and human beings. So, a rapid protection should be provided in emergency cases to save the national animal wealth. Many live and inactivated rabies vaccine were successfully used to protect farm animals pre-exposure (Barnas, 2001, Green, 2006; Khodeir and Daoud, 2008 and Albehwar, 2009).

The development of antiviral drugs is still in its infancy with rapid changes and progressive milestones encountered almost daily. The last two decades have been the most dynamic in the history of viral infections and their management. Unfortunately, antiviral drugs have been effective for only a few groups of viruses up until now. Most antiviral drugs do not produce a cure, but rather allow control of the infection. However, the limitations of antiviral therapy, including the high costs of drugs, make the need for prevention even more urgent (Trying, 2005).

The present study aims mainly to determine the best way to stop rabies infection in naturally exposed victims through the application of antiviral treatment in a comparison with the efficacy of emergency immunization using rabies antiserum and vaccine. 


\section{MATERIAL AND METHODS}

\section{1-Rabies viruses:}

\section{1-Challenge virus strain (CVS):}

Mice brain adapted rabies virus was supplied by the Department of Pet Animal Vaccine Research (DPAVR), Veterinary Serum and Vaccine Research Institute (VSVRI), Abassia Cairo. It had a titer of $10^{6} \mathrm{ML}$ $\mathrm{ID}_{50} / \mathrm{ml}$. This virus was used for experimental injections of mice.

\section{2- Cell culture adapted rabies virus:}

ERA strain of rabies virus adapted to BHK cell culture was supplied by the same department with a titer of $10^{6.5}$ TCID $50 / \mathrm{ml}$ and used to study the in vitro antiviral effect of Acyclovir and Ribavirin.

\section{2-Mice:}

Three hundred and fifty Swiss albino weaned mice (4 weeks old) were supplied by DPAVR and used in the antiviral assay.

\section{3-Drugs:}

\section{1-Virin:}

It was supplied by SIGMA Pharmaceutical Industry Combany in the form of tables. Each tablet contains $400 \mathrm{mg}$ Ribavirin.

\section{2-Acyclovir:}

It was supplied by MyIAN as a solution of concentration of 250 $\mathrm{mg} / \mathrm{ml}$. Both drugs were tested to their antiviral effect against rabies virus in vitro in BHK cells and in vivo in experimental infected mice. 


\section{4-Anti-rabies hyper immune serum:}

Anti-rabies hyper immune serum (Khodeir and Daoud, 2008) was supplied by DPAVR with a titer of $130 \mathrm{IU} / \mathrm{ml}$ and used as antiviral agent in a comparative manner with the effect of Acyclovir and Ribavirin against experimental infection of mice.

\section{5-Cell culture:}

Baby hamster kidney cell line $\left(\mathrm{BHK}_{13}\right)$ was supplied by DPAVR and used in vitro antiviral assay and detection of the cell toxicity of Ribavirin and Acyclovir.

\section{6- Testing the cell toxicity of Ribavirin and Aciclovir:}

Ten fold serial dilutions of each drug were prepared in HBSS. Each dilution of each drug was inoculated in 5 wells of 96 well micro-titer plate containing BHK cells. Normal BHK cells were kept as control. The cytotoxic effect of the tested drugs was determined by the induced changes in the cell morphology and growth degree.

\section{7-In vitro antiviral assay:}

Ten fold serial dilutions of Ribavirin and acyclovir were tested against ERA strain of rabies virus in BHK cell culture in micro-titer plates. Each drug dilution was tested against 100 TCID $_{50}$ of the virus in each of 5 wells of 96 well micro-titer plates. The test included cell and virus controls. The antiviral effect of tested drugs was determined by inhibition of the cytopathic effect (CPE) of the virus.

\section{8- In vivo antiviral assay:}

The mice were divided into 6 groups as follows: 
Group 1; 2 and 3 (100 mice/group) were experimentally infected with the CVS through the intracerebral route using $0.03 \mathrm{ml} /$ mouse.

Group (1) was subdivided into 10 subgroups which were treated with Ribavirin inoculated I/P using a dose of $6.25 \mathrm{mg} / \mathrm{mouse}$ on the $0,1,2,3,4,5,6,7,8,9$ and 10 days post infection. Each subgroup was treated by the same dose for the following days of the experiment.

Group (2) was subdivided into 10 subgroups (10 mice/subgroup) treated with $31.25 \mathrm{mg}$ Acyclovir/mouse inoculated I/P on the same periods post infection. Each subgroup was treated by the same dose for the following days of the experiment.

Group (3) was subdivided into 10 subgroups (10 mice/subgroup) treated with anti-rabies hyper immune serum using $30 \mathrm{IU} /$ mouse according to Khodeir and Daoud (2008) inoculated I/P on the same periods post infection.

Group (4) was inoculated with Ribavirin only.

Group (5) was inoculated with Acicloviry only.

Group (6) was inoculated with anti-rabies hyper immune serum

Group (7) was infected with the CVS and did not receive any treatment.

Group (8) was kept without injection and without treatment.

Each of group 4, 5, 6 and 7 was consisted of 10 mice and kept as control.

All mice were kept under hygienic measures receiving balanced ration and adequate water and subjected to daily observation. 


\section{RESULTS AND DISCUSSION}

Table (1): In vitro effect of Ribavirin on normal and infected BHK cell cultures with rabies virus

\begin{tabular}{|c|c|c|}
\hline Tested concentration $(\mu \mathrm{g} / \mathrm{ml})$ & Cytotoxic effect & $\begin{array}{c}\text { Antiviral effect against } 100 \text { TCID }_{50} \\
\text { Of rabies virus }\end{array}$ \\
\hline Normal BHK cell control & \multirow{7}{*}{$\begin{array}{c}\text { No effect on the cell growth and } \\
\text { viability }\end{array}$} & \multirow{7}{*}{$\begin{array}{l}\text { Complete inhibition of the CPE of } \\
\text { rabies virus }\end{array}$} \\
\hline 1 & & \\
\hline 5 & & \\
\hline 10 & & \\
\hline 50 & & \\
\hline 100 & & \\
\hline 200 & & \\
\hline $\begin{array}{l}\text { Infected untreated BHK cell } \\
\text { culture control }\end{array}$ & Characteristic $\mathrm{CPE}$ of rabies virus & \\
\hline
\end{tabular}

Table (2): In vitro effect of acyclovir on normal and infected BHK cell cultures with rabies virus

\begin{tabular}{|c|c|c|}
\hline $\begin{array}{l}\text { Tested concentration } \\
\text { Of Acycolvir }\end{array}$ & Cytotoxic effect & $\begin{array}{l}\text { Antiviral effect against } 100 \\
\operatorname{TCID}_{50} \mathrm{Of} \text { rabies virus }\end{array}$ \\
\hline $\begin{array}{l}\text { Normal untreated BHK cell } \\
\text { culture control }\end{array}$ & \multirow{5}{*}{$\begin{array}{c}\uparrow \\
\text { No effect on the cell growth and } \\
\text { viability } \\
\downarrow\end{array}$} & NO antiviral effect \\
\hline 1 & & \multirow{4}{*}{$\begin{array}{c}\uparrow \\
\text { Complete inhibition of the CPE of } \\
\text { rabies virus } \\
\downarrow\end{array}$} \\
\hline 10 & & \\
\hline 100 & & \\
\hline 200 & & \\
\hline $\begin{array}{c}\text { Untreated infected BHK cell } \\
\text { culture }\end{array}$ & \multicolumn{2}{|c|}{ Characteristic CPE of rabies virus } \\
\hline
\end{tabular}

$\overline{\text { Kafrelsheikh Vet. Med. J. Vol. } 10 \text { No. } 2 \text { (2012) }}$ 
Table (3): In vivo antiviral activity of ribavirin against rabies virus infection in mice

\begin{tabular}{|c|c|c|c|c|}
\hline $\begin{array}{l}\text { Mice subgroups } \\
\text { in group-1 }\end{array}$ & $\begin{array}{c}\text { Days of treatment } \\
\text { post infection }\end{array}$ & $\begin{array}{c}\text { Number of treated } \\
\text { infected mice }\end{array}$ & $\begin{array}{c}\text { Number of } \\
\text { survived mice }\end{array}$ & $\begin{array}{l}\text { Protection } \\
\text { percentage }\end{array}$ \\
\hline 1 & 0 & 10 & 10 & 100 \\
\hline 2 & 1 & 10 & 10 & 100 \\
\hline 3 & 2 & 10 & 9 & 90 \\
\hline 4 & 3 & 10 & 7 & 70 \\
\hline 5 & 4 & 10 & 4 & 40 \\
\hline 6 & 5 & 10 & 2 & 20 \\
\hline 7 & 6 & 10 & 1 & 10 \\
\hline 8 & 7 & 10 & 0 & 0 \\
\hline 9 & 8 & 10 & 0 & 0 \\
\hline 10 & 9 & 10 & 0 & 0 \\
\hline \multicolumn{2}{|c|}{$\begin{array}{l}\text { Group-4 received ribavirin only as drug } \\
\text { control }\end{array}$} & 10 & \multicolumn{2}{|c|}{$\begin{array}{l}\text { Remained healthy allover the } \\
\text { experimental period }\end{array}$} \\
\hline \multicolumn{2}{|c|}{ Group-7 untreated infected control mice } & 10 & \multicolumn{2}{|c|}{$\begin{array}{c}\text { Showed characteristic signs of rabies } \\
\text { started by the } 4^{\text {th }} \text { day post infection and } \\
\text { ended with death by the } 6-7^{\text {th }} \text { day with } \\
0 \% \text { protection }\end{array}$} \\
\hline \multicolumn{2}{|c|}{ Group-8non-infected untreated control mice } & 10 & \multicolumn{2}{|c|}{$\begin{array}{l}\text { Remained healthy allover the } \\
\text { experimental period }\end{array}$} \\
\hline
\end{tabular}

Table (4): In vivo antiviral activity of Acyclovir against rabies virus infection in mice

\begin{tabular}{|c|c|c|c|c|}
\hline $\begin{array}{l}\text { Mice subgroups in } \\
\text { group-2 }\end{array}$ & $\begin{array}{l}\text { Days of treatment } \\
\text { post infection }\end{array}$ & $\begin{array}{c}\text { Number of treated } \\
\text { infected mice }\end{array}$ & $\begin{array}{c}\text { Number of } \\
\text { survived mice }\end{array}$ & $\begin{array}{l}\text { Protection } \\
\text { percentage }\end{array}$ \\
\hline 1 & 0 & 10 & 10 & 100 \\
\hline 2 & 1 & 10 & 10 & 100 \\
\hline 3 & 2 & 10 & 10 & 100 \\
\hline 4 & 3 & 10 & 7 & 70 \\
\hline 5 & 4 & 10 & 4 & 40 \\
\hline 6 & 5 & 10 & 2 & 20 \\
\hline 7 & 6 & 10 & 1 & 10 \\
\hline 8 & 7 & 10 & 0 & 0 \\
\hline 9 & 8 & 10 & 0 & 0 \\
\hline 10 & 9 & 10 & 0 & 0 \\
\hline \multicolumn{2}{|c|}{$\begin{array}{l}\text { Group-5 received acyclovir only as drug } \\
\text { control }\end{array}$} & 10 & \multicolumn{2}{|c|}{$\begin{array}{l}\text { Remained healthy allover the } \\
\text { experimental period }\end{array}$} \\
\hline \multicolumn{2}{|c|}{ Group-7 untreated infected control mice } & 10 & \multicolumn{2}{|c|}{$\begin{array}{l}\text { Showed characteristic signs of rabies } \\
\text { started by the } 4^{\text {th }} \text { day post infection and } \\
\text { ended with death by the } 6-7^{\text {th }} \text { day with } \\
0 \% \text { protection }\end{array}$} \\
\hline \multicolumn{2}{|c|}{ Group-8non-infected untreated control mice } & 10 & \multicolumn{2}{|c|}{$\begin{array}{l}\text { Remained healthy allover the } \\
\text { experimental period }\end{array}$} \\
\hline
\end{tabular}

Kafrelsheikh Vet. Med. J. Vol. 10 No. 2 (2012) 
Effects Of Some Antiviral Agents In Emergency Cases Of...

Table (5): Efficacy of rabies hyper immune serum against rabies infection in mice

\begin{tabular}{|c|c|c|c|c|}
\hline $\begin{array}{l}\text { Mice subgroups } \\
\text { in group-3 }\end{array}$ & $\begin{array}{c}\text { Days of treatment } \\
\text { post infection }\end{array}$ & $\begin{array}{c}\text { Number of treated } \\
\text { infected mice }\end{array}$ & $\begin{array}{l}\text { Number of } \\
\text { survived mice }\end{array}$ & $\begin{array}{l}\text { Protection } \\
\text { percentage }\end{array}$ \\
\hline 1 & 0 & 10 & 10 & 100 \\
\hline 2 & 1 & 10 & 9 & 90 \\
\hline 3 & 2 & 10 & 8 & 80 \\
\hline 4 & 3 & 10 & 8 & 8- \\
\hline 5 & 4 & 10 & 7 & 70 \\
\hline 6 & 5 & 10 & 5 & 50 \\
\hline 7 & 6 & 10 & 3 & 30 \\
\hline 8 & 7 & 10 & 0 & 0 \\
\hline 9 & 8 & 10 & 0 & 0 \\
\hline 10 & 9 & 10 & 0 & 0 \\
\hline \multicolumn{2}{|c|}{$\begin{array}{l}\text { Group-6 received rabies hyper immune } \\
\text { serum only }\end{array}$} & 10 & \multicolumn{2}{|c|}{$\begin{array}{c}\text { Remained healthy allover the } \\
\text { experimental period }\end{array}$} \\
\hline \multicolumn{2}{|c|}{ Group-7 untreated infected control mice } & 10 & \multicolumn{2}{|c|}{$\begin{array}{l}\text { Showed characteristic signs of rabies } \\
\text { started by the } 4^{\text {th }} \text { day post infection and } \\
\text { ended with death by the } 6-7^{\text {th }} \text { day with } \\
0 \% \text { protection }\end{array}$} \\
\hline \multicolumn{2}{|c|}{ Group-8non-infected untreated control mice } & 10 & \multicolumn{2}{|c|}{$\begin{array}{c}\text { Remained healthy allover the } \\
\text { experimental period }\end{array}$} \\
\hline
\end{tabular}

As it is well known that the majority of viral diseases are incurable and vaccination against them is the corner stone in their control and protection of susceptible hosts. According to the dramatic sequel of rabies causing great economic losses and public health hazard; usually there is an attention directed toward how eliminate or minimize spread of infection.

The development of antiviral drugs is still in its infancy with rapid changes and progressive milestones encountered almost daily. The last two decades have been the most dynamic in the history of viral infections and their management. Unfortunately, antiviral drugs have been effective for only a few groups of viruses up until now. Most antiviral drugs do not produce a cure, but rather allow control of the infection. However, the limitations of antiviral therapy, including the high costs of drugs, make the need for prevention even more urgent (Trying, 2005). 
The obtained results tabulated in table (1) indicated the efficacy and safety of ribavirin as potent anti-rabies in BHK cell culture. Neither inhibition of cell growth nor cytotoxicity have been induced while antiviral effect was clearly demonstrated in infected cell culture with any of $1,5,10,50,100$ and $200 \mu \mathrm{g} / \mathrm{ml}$ of ribavirin. These results are extra addition to the broad spectrum of ribavirin against many viruses. Ribavirin has been reported to inhibit the replication of influenza and parainfluenza viruses as stated by Brown (1979) and Brown et al (1980 and 1981). The antiviral effect of ribavirin was explained on the fact that it inhibits the host cell enzyme inosine monophosphate dehydrogenase causing a depletion of the cellular quanosine nucleotide pool as shown by Streeter et al (1973). In addition, Barry (1964) concluded that ribavirin inhibits cellular mRNA synthesis.

In vitro investigation of the cytotoxic effect of acyclovir on BHK cells showed that all tested concentrations (1, 10, 100 and $200 \mu \mathrm{g} / \mathrm{ml}$ ) were found to be safe showing neither morphological abnormalities nor growth retardation. These findings come in agreement with those reported by Whitley (2010; Yunhao et al (2004) and Mahmoud et al (2005).

In Vitro studies revealed that all tested concentrations of Acyclovir were found to be safe for Vero cell showing no cell toxicity and did not affect the cell growth kinetics but showed detectable antiviral effect against canine hepatitis virus and it was valuable to reduce the severity of experimental infection of puppies with the virulent virus (El-Gallad, 2008). 
Acyclovir is a guanine analogue commonly used antiviral drug of low cytotoxicity and primarily used for treatment of herpes simplex virus infection (Gertrude, 1988). It contains only a partial nucleotside structure and the sugar ring is replaced by an open-chain structure. It is selectively converted into acyclo-guanosine monophosphate (acycloGMP) by viral thymidine kinase, which is far more effective (3000 times) in phosphorylation than cellular thymidine kinase. Subsequently, the monophosphate form is further phosphorylated into active triphosphate form, acyclo-guanosine triphosphate (acyclo-GPT), by cellular kinase. Acyclo-GTP is a very potent inhibitor of viral DNA polymerase; it has approximately 100 times greater affinity for viral than cellular polymerase. As a substrate, acyclo-GMP is incorporated into viral DNA, resulting in chain termination. It has also been shown that viral enzymes cannot remove acyclo-GMP from the chain, which results in inhibition of further activity of DNA polymerase. It was recorded that acyclovir reduced the titer of herpes virus type-1 (a DNA virus) in Vero cells and in skin samples from experimentally infected mice (Piret et al, 2000). It is also known as ACV or acycloguanosine, as a selective antiviral agent indicated for the treatment of certain herpes virus infections.

Complete antiviral effect against 100 TCID $_{50}$ of rabies virus was obtained with $10 ; 100$ and $200 \mu \mathrm{g} / \mathrm{ml}$ (Table-2). Similar results were reported by Gertrude (1988); Kleymann et al (2002); Lyu et al (2005) and El-Gallad (2008) who suggested that acyclovir is selectively converted into acyclo-guanosine monophosphate (acyclo-GMP) by viral thymidine kinase, which is far more effective in phosphorylation than cellular thymidine kinase. Subsequently, the monophosphate form is 
further phosphorylated into active triphosphate form, acyclo-guanosine triphosphate (acyclo-GPT), by cellular kinase. Acyclo-GTP is a very potent inhibitor of viral DNA polymerase; it has approximately 100 times greater affinity for viral than cellular polymerase.

In vivo studies indicated that acyclovir injection provided $80 \%$ (table -4). In this respect parallel results were obtained by Piret et al (2000) who found that acyclovir reduced the titer of herpes virus type-1 (a DNA virus) in Vero cells and in skin samples from experimentally infected mice. Also El-Gallad (2008) recorded a detectable antiviral effect of acyclovir against canine hepatitis virus and it was valuable to reduce the severity of experimental infection of puppies with the virulent virus.

About the experimental infection of mice with the CVS; it was found that mice received rabies antiserum were able to survived the infection when the antiserum was administrated on the $o, 1^{\text {st }}, 2^{\text {nd }}$ and $3^{\text {rd }}$ day post infection but those mice received the treatment on the following days did not survive the infection and showed paralysis of the hind limbs by the $4^{\text {th }}$ day and died by the $6-7^{\text {th }}$ day post infection. These observations indicate that passive immunization against rabies should be as soon as possible post exposure and the late administration leads to fast disease arise. There were no available data that discuss emergency immunization of animals against rabies but Barnas (2001) stated that it is recommended that all unvaccinated individuals with animals bites receive immediate treatment with human rabies immune globulin (HRIG) injected into and around the wound followed by rabies vaccination the thing which could be applied for farm animals. Also, 
Khodeir and Daoud (2008) and Albhwar (2009) showed that post exposure immunization of animals should be carried out as soon as possible on time post exposure recommended the same periods. They added that either homologous or heterologous species anti-rabies sera could be used safely in emergency cases.

\section{REFERENCES}

- Barnas, G.P. (2001): Rabies vaccination. WHO position, weekly epidemiological record, 77: 109-120

- Bourhy, H.; Reynes, J.M.; Dunham, E.J.; Dachaux, L.; Larrous, F.; Houng, V.T.Q.; Yan, J.; Miranda, M.E.G. and Holmes, E.C. (2009): The origin and phylogeography of dog rabies virus. J.

Gen. Virol. 89: 2673-2681

- El-Gallad, S.B. (2008): Investigation of the antiviral effect of Ribavirin and Acyclovir on Canine Distemper and Infectious Canine Heapatitis viruses. SCVMJ, XIII (2).

- Green, C.E. and Rupprecht, C.E. (2006): Rabies and other Lyssavirus infectons. Infec.Dis.Dog and Cat., $3^{\text {rd }}$ Ed.:167-183.

- Kaku, Y.; Nough, A.; Hottak, L.; Yamada, A. and Inoues, S. (2011): Inhibition of rabies virus propagation in mouse neuro balstoma cells by an antibody against the viral protein. Virol.: 162-178.

- Khodeir, M.H. and Daoud, A.M. (2008): Preparation of antirabies hyperimmune serum for emergency immunization of farm animals. $4^{\text {th }}$ Int. Sci. Conf. NRC, 1-9. 
- Nishizono, A. (2009): Rotavirus infection with multiple emerging genotypes in Sri Lanka. Division of Infectious Diseases, Department of Social and Environmental Medicine, Institute of Scientific Research, Oita University Arch.

- Radostits, O.M.; Gay, C.C.; Hinchcliff, K.W. and Constable, P.D. (2007): Diseases of cattle, horses, sheep, pigs and goats. $10^{\text {th }} \mathrm{Ed}$., Saunders, Elsevier, New York, USA.

- Rupporecht, C.E.; Briggs, D. and Brown, C.M. (2010): Use of a reduced ( 4 doses) vaccine schedule for post exposure prophylaxis to prevent human rabies recommendations of the advisory committee on immunization practices. MMWR Recomm Rep. 2010: 59: 1-9.

- Trying, S.K. (2005): Antiviral agents; vaccines and immunotherapies (Preface).

- Acyclovir in the treatment of hand-foot-and-mouth disease: Department of Medicine, Medical College of Ohio, Toledo 436990008, USA.

- Woldehiwet, Z. (2005): Clinical laboratory advances in the detection of rabies virus. Dep. Vet. Pathol. Vet. Teaching Hospital, Univ. Liverpool, Leahurst, Neston Wiral, Ch 647 TE, 351 (1-2): 49-63. 
تأثير بعض مضادات الفيروسات في حالات الإصابة بالسعار الاضطر ارية ممثلة في الفئر ان

هذه الدراسة تهدف بشكل رئيسي لتحديد أفضل وسيلة لوقف عدوى داء الكلب فى الضحايا الذين تعرضوا بشكل طبيعي من خلال تطبيق العلاج المضاد للفيروسات فى مقارنة مع فعالية التحصين في حالات الطوارئ باستخدام مصل لقاح داء الكلب. أظهرت النتائج التى تم الحصول عليها ما يلى:

1- كل تركيزات الريبافيرين والاسيكلوفير لا تحول دون معدل نمو الخلايا ولم تؤثر على شكل الخلايا مما يدل على سلامة الدواء.

2- الدراسات فى المختبر أظهرت أة الريبافيرين والاسيكلوفير قادرين على منع التأثير الضار من فيروس داء الكلب فى الخلية المصابة.

3- أنتتت الدراسة أن أفضل وقت لتلقى علاج الريبافيرين بين اليوم الأول للعدوى ويومين بعد العدوى تبين حماية بنسبة 100\% تليها العلاج فى اليوم الثالث من العدوى 90\% حماية ثم فى اليوم الرابع 70\% حماية وتأخر العلاج يؤدى الى حماية أقل 40\% تتخفض تدريجيا الى 10\% من

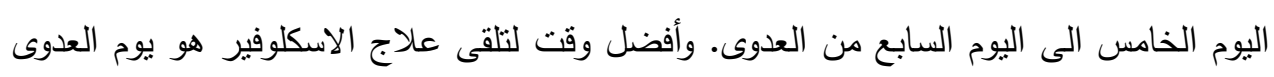
واليوم الثانى والثالث بعد العدوى للفيران من فيروس السعارقادر على الحماية بنسة 100\% تليها حماية 80\% مع تطبيق العلاج فى اليوم الرابع والفئران التى تلقت العلاج بعد ذلك تكون غير قادرة على تحمل أعراض السعار .

4- إعطاء مصل داء الكلب للفئران المصابة معمليا بالمرض أدت الى حماية 100\% ، 90\% ، 80\% ، 70\% فى حالات إعطائها فى وقت الإصابة واليوم الأول والثانى والثالث والرابع على التوالى والتأخر فى إعطاء المصل أدى إلى تقليل نسبة الحماية من 50\% فى اليوم الخامس الى صفر \% فى اليوم السابع من العدوى. 